\title{
Peace Management and Conflict Resolution: A Practitioner's Perspective
}

\author{
Ibrabim A. Gambari
}

\section{INTRODUCTION}

In order to address violent conflicts across the world, international collaboration and astute coordination are required. This is not possible without an urgent, overall enhancement of global and regional mechanisms for peace management and conflict resolution. Currently, 65 million of the approximately 7.6 billion people on earth are forcibly displaced persons (FDPs). This situation is but a symptom of protracted conflicts mainly in ten countries/areas- Afghanistan, Iraq, Syria, Burundi, Democratic Republic of the Congo (DRC), Somalia, Sudan, Colombia, the Caucasus, and the former Yugoslavia. In addition, 32 other countries have been the source of a large number of refugees and 53 countries are involved in managing internally displaced persons (IDPs). ${ }^{1}$

This chapter will discuss the broad issues of prevention, as well as mediation of conflicts, followed by a brief synopsis of three

\section{A. Gambari $(\bowtie)$}

Former Head of the United Nations/African Union Mission in Darfur, and founder and former Chairman of Savannah Centre for Diplomacy, Democracy and Development, Abuja, Nigeria

T. McNamee and M. Muyangwa (eds.), The State of Peacebuilding in Africa, https://doi.org/10.1007/978-3-030-46636-7_16 
case studies in violent conflict-Cyprus, Myanmar, and Darfur. The subsequent outlining of key peacebuilding challenges and conclusions are drawn in part from my personal experience in the management and attempted resolution of these conflicts, principally in my former role as the Joint Special Representative of the UN Secretary-General, Chief Mediator and Chairperson of the African Union/Head of the UN-African Union Mission in Darfur (UNAMID). Other relevant experiences drawn on below are my role as UN Secretary General's Special Representative and Head of the UN Mission in Angola, and the UN Under SecretaryGeneral/Special Adviser on Africa heading the Office, which was the focal point for promoting and coordinating international support for the New Partnership for African Development (NEPAD).

The United Nations (UN) is premised on the concept of collective security: the idea that a threat to peace anywhere should be considered a threat to peace everywhere and should be met with a collective response based on global solidarity. In reality, however, the record of the international community in conflict management and conflict resolution is mixed. On the positive side, the Human Security Report of 2005 found a 40 percent decline in violent conflicts between 1992 and $2004 .^{2}$ The report attributed this, in part, to the efforts made by UN peacemaking. Nonetheless, we are all living witnesses to the mass suffering caused by prolonged ongoing conflicts in many parts of the world. Examples of failures of collective security are not hard to find.

We need to better understand the reasons for relative successes in global peacemaking, as well as conspicuous failures, and adapt our strategies and capacities in order to produce more durable, negotiated solutions. In this regard, we need to recognize that the nature of conflict-its root causes, the type of protagonists-has changed.

Three evolving conflict dynamics stand out:

i. Violence is overwhelmingly intra-state;

ii. the number of non-state actors involved is growing; and

iii. non-state actors have added more complexity to the root causes and management of conflict.

Both in academia and among diplomats, there are choices and preferred approaches to conflict resolution. Opinions differ on why mediation efforts, especially for intractable conflicts, fail. My own experience suggests that the prescription of "one-size-fits-all" solutions is often to blame. Most conflicts feature complex interactions of different forces, 
with each requiring well-designed structures and responses that are oriented to the needs of the specific situation.

What have come to be known as "spoilers" in a peace process are an endemic problem. ${ }^{3}$ Whether real or potential, leaders of parties or movements, either within or outside a peace process, spoilers are typically thought to constitute themselves as deliberate obstacles to the peaceful settlement of conflicts and employ violence to achieve their objectives. At the same time, it is not clear whether the term "spoiler" is ascriptive or earned, whether they are homegrown or externally generated. My own experience suggests that the spoilers of today can become the partners of peace tomorrow.

Africa has the most developed regional organization in the developing world for conflict resolution and peace management. The African Union (AU) was founded in May 2001 in Addis Ababa (and launched in Durban, South Africa in 2002), as a successor to the Organization of African Unity (OAU), which came into being in $1963 .{ }^{4}$ The first OAU peacekeeping operation was in Chad in December 1981. Beset by myriad problems, and without assistance from the UN, it lasted only until June 1982. On the whole, the OAU's efforts to maintain peace and security in Africa were mostly weak and ineffectual. ${ }^{5}$ Thus, the transformation of the OAU to $\mathrm{AU}$ can be understood as a reinvigoration of the organization in tackling Africa's security challenges.

The AU has a Peace and Security Council, and a Department of Peace and Security, headed by a Commissioner working with (not under) the Chairperson of the African Union Commission. One of the more significant developments in the history of the AU is the formation of the African Standby Force (ASF). My experience in leading the assessment of military and civilian experts on making the ASF fully operational reaffirmed my belief in its necessity for Africa, though the challenge of creating a deployable force still remains at the time of writing.

By 2019, AU peacekeeping/peace-enforcement missions were deployed in Somalia and there was also a Joint AU/UN Peacekeeping Mission in Darfur. The latter was, until recently, the largest international peacekeeping force. At its peak and under my leadership as Joint Special Representative, the AU had about 30,000 military, police, and civilian personnel. It was also the most expensive mission, with an annual budget of between US $\$ 1.5$ billion and US $\$ 1.7$ billion. $^{6}$

Finally, there is the Panel of the Wise, comprising select former statesmen and stateswomen. The Panel was created in late 2002 and became operational in 2008. It boasts several subregional counterparts. 
Collectively, these organs and structures are known as the AU Peace and Security Architecture (APSA). ${ }^{7}$

The AU's APSA is underpinned by the now commonly held view that there is a strong nexus between peace, security, development, human rights, and democratization. Two seminal reports bear out this key relationship, the first in 1992 by the then-UN Secretary-General Boutros Boutros-Ghali, An Agenda for Peace ${ }^{8}$ and the second, by his successor, Kofi Annan, In Larger Freedom.

\section{Cyprus and Myanmar-Lessons for Africa?}

Cyprus is one of the longest running conflicts in the dossier of the UN. There has been both a UN peacekeeping operation deployed there since 1964, the year after hostilities broke out, as well as the Secretary-General's Good Offices Mission Role after 1974. The latter was encouraged by the Security Council following the division of the country into two hostile camps of Greek Cypriots and Turkish Cypriots-as well as the presence of Turkish troops in Cyprus.

The admission of a divided country, Cyprus, as a full member of the European Union has been a complicating factor in seeking a resolution of the conflict. The UN has remained a key third party continuously seeking a formula that would lead to a bizonal, bicommunal federal state. ${ }^{10}$ Unfortunately, each community in Cyprus has regarded the other as the "spoiler" in the peace process. That much was clear to me during my short time as UN Secretary-General's Special Envoy on Cyprus in the mid-2000s. This situation is common in Africa, where the idea of "spoilers" is bandied about, without consideration for what their objectives might actually entail. In the case of Cyprus, it is fair to say some have broader national and international objectives, while others are more limited. But, as in parts of Africa, it is an open question whether some are bent on prolonging the stalemate forever.

Nearly fifty years on, there is no tangible sense of urgency in resolving the conflict in Cyprus. It has been compared to "a padlock requiring four keys, held respectively by the Greek Cypriots, the Turkish Cypriots, Greece and Turkey." In the words of another former Special Envoy, Alvaro de Soto, who handled the dossier on behalf of UN SecretaryGeneral Kofi Annan, the history of attempts to overcome the division of Cyprus can be measured in false dawns. One or another leader could always be relied upon to thwart the effort and yell "no!", and support 
from either Ankara or Athens would be withdrawn. ${ }^{11}$ The most comprehensive plan to resolve the conflict, which was presented by the UN to the parties and also had the blessing of the European Union, was put to referenda in 2004. It was approved by the Turkish Cypriots but turned down by the Greek Cypriots. More than fifteen years on, it is unclear if Cyprus is any closer to a durable solution or on the cusp of another false dawn.

Myanmar was once thought to be one of the world's most intractable internal conflicts, as stubborn as any long-running conflict in Africa, pitching the military versus the people. It is a country that was once beset by grave human rights abuses, and its democratic prospects in the 1990s seemed dim. The UN attempted to mobilize the support of neighboring countries and other key states through the SecretaryGeneral's special envoys and advisors. Their role would be to assist the Government of Myanmar in implementing its Seven Steps Road Map toward democracy, announced by General Khin Nyunt in 2003, which would mean addressing the country's multi-dimensional problems (human rights, forced labor, child soldiers, humanitarian access and delay in achieving Millennium Development Goals, etc.).

The failure of past engagements with Myanmar was due to issues around its international isolation, economic sanctions, and Security Council Resolutions against the regime.

In pursuing the Secretary-General's Good Offices Role in Myanmar as the third Special Envoy, I was given a formidable set of tasks. Four main principles guided my efforts:

i. Ensuring that the Secretary-General's Good Offices was perceived as a process and not an event;

ii. Given the complexities of the Myanmar conflict, not reducing our approach to a single issue (e.g., freedom for imprisoned democracy leader and Nobel Peace Prize winner, Aung San Sun Kyi, however important a priority that may have been);

iii. Engaging with the Government-and, to an extent, the opposition-could not be an end in itself, instead there must be progress, measurable in concrete terms; and

iv. Engaging with all those, both inside and outside the country, who could contribute to addressing Myanmar's challenges. 
In line with these principles, and with support from the Association of Southeast Asia Nations (ASEAN), China, India, Japan, and others, my role was to bring the government and the opposition leaders together to commence a political process. In doing so, it was not uncommon to feel the wrath of exiled groups in Thailand, London, and the United States and some key members of the Security Council, who did not want the country's National League for Democracy and its leadership to participate in the elections, which they saw as illegitimate. I was convinced then, and proved right subsequently, that without the elections, there was not a viable path to the release of Aung San Suu Kyi and the resolution of the political deadlock in Myanmar. As it happened, the newly elected president undertook dramatic and significant reform measures aimed at promoting democracy and transforming the largely centralized economy into an increasingly market-oriented one. Myanmar subsequently moved from one positive milestone to another, including chairmanship of ASEAN and, via elections, the elevation of San Suu Kyi to a position equivalent to prime minister. However, the massacre of Rohingyas beginning in early 2018 and the consequent collapse of San Suu Kyi's global reputation illustrates how much more needs to be done to cement the democratic gains of the past decade and to reaffirm peaceful coexistence and respect for human rights in Myanmar.

\section{DARFUR/SUDAN}

In 2009, the AU High-Level Panel on Darfur, led by former President Thabo Mbeki of South Africa, defined the Darfur conflict as "Sudan's crisis in Darfur." In doing so, the Panel stated that "the root of the Darfur crisis lies in the history of neglect of the Sudanese peripheries, dating from colonial times and continuing during the years of Sudan's independence." 12 In other words, the conflict should not be seen in terms of identity: Arabs versus Africans, Christian versus Muslims, or North versus the South. ${ }^{13}$ Rather, and especially following the separation of South Sudan from the rest of the country in July 2011, it's a conflict over access to resources (especially water), power (largely concentrated in Khartoum) and economic opportunities. The reason so many past agreements were "dishonored" is partly down to a misdiagnosis of the problem. ${ }^{14}$ The centrality of access to water, in particular, was my main motivation as Head of the African Union-UN Hybrid Operation in 
Darfur (UNAMID), to organize a large international forum on Water for Peace.

Following an escalation of violence in the region and subsequent humanitarian crisis in 2003-2004, ceasefire agreements were brokered and the first contingent of military observers and protection forces were deployed. This marked the beginning of the AU Mission in Sudan (AMIS). ${ }^{15}$ Its initial success in stabilizing the situation on the ground was not followed by a Comprehensive Peace Agreement, which could have paved the way for peace and development in Darfur. The challenges on the ground were formidable: protection of a dispersed civilian population and the delivery of humanitarian assistance to over 2 million internally displaced persons and 300,000 refugees. AMIS, despite some support from international partners, could not cope. After initial resistance from the Government of Sudan, they eventually agreed to allow in UNAMID. This AU-UN hybrid mission was arguably, at the time, the most extensive collaboration ever mounted between a global and regional organization in the area of peace and security. UNAMID took over from AMIS on January 1, 2008. If anything, AMIS showed that Africa is willing to put its boots where its politics lay. And when the history of Darfur is written, the work of AMIS should be viewed as essential to averting what could have been another Rwanda. ${ }^{16}$

Stark challenges remain in Darfur today. There are still significant parties to the conflict which are not signatories to the peace process. But the current situation is vastly better than what obtained in Darfur in the 2000s. The signing of the Doha Document for Peace in Darfur (DDPD) on July 14, 2011 between the Government of Sudan and one of the armed movements, Liberation and Justice Movement, was a significant early milestone. Thereafter followed a number of positive developments, including the establishment of a Darfur Regional Authority and an international Donor Conference on Reconstruction and Development in Darfur in 2013, where over US $\$ 3$ billion was pledged. The periodic outbreaks of violence since then illustrate that more work needs to be done, especially in improving local capacities for addressing the root causes of protracted violent conflict.

In his Report on Enhancing Mediation and Its Support Activities (S/2009/189 of 8 April 2009), then-UN Secretary-General, Ban Ki Moon, made urgent recommendations on the management of conflict and achieving peace. These include: 
i. The need for experienced and knowledgeable mediators and support teams;

ii. the need for sufficient resources to help parties design and pursue processes which address root causes of conflicts and achieve agreements which lead to durable peace; and

iii. the need for building capacities for mediation at the local, national, and regional levels, while promoting coherent partnerships between the UN, regional and subregional organizations, member states and NGOs.

\section{Key Challenges}

\section{Striking a Balance Between Peace and Justice, Including Strengthening Relations Between the United Nations and the International Criminal Court}

The first challenge lies in the increased demands on the UN to both facilitate the negotiation of peace agreements and to establish accountability mechanisms. This has led us to examine the relationship between the UN and the International Criminal Court (ICC), and the interaction between UN representatives and persons indicted by the ICC. While in the long run, peace and justice are mutually reinforcing, in the short run there are often tensions between these two essential goals. As then-UN Secretary-General Kofi Annan stated before the Security Council in 2003,

We should know that there cannot be real peace without justice, yet the relentless pursuit of justice may sometimes be an obstacle to peace. If we insist, at all times and in all places, on punishing those who are guilty of extreme violations of human rights, it may be difficult or even impossible to stop the bloodshed and save innocent civilians. If we always and everywhere insist on uncompromising standards of justice, a delicate peace may not survive. But equally, if we ignore the demands of justice simply to secure agreements, the foundations of that agreement will be fragile and will set bad precedents. ${ }^{17}$

To help manage these tensions, the UN Secretariat came to the following conclusions:

i. On the relationship between peace and justice: there is no sustainable peace without justice-although they can be sequenced in time; 
ii. The UN does not recognize amnesty for genocide, crimes against humanity, war crimes, and other serious violations of international humanitarian law;

iii. On the UN-ICC relationship: while the ICC is independent of the UN, the UN supports the Court and avoids any action likely to undermine its authority; and

iv. Contacts between UN representatives and persons holding positions of authority in their country who have been indicted by the ICC should be limited to what is strictly required for carrying out $\mathrm{UN}$-mandated activities.

The preamble to the 1998 Rome Statute, which created and governs the ICC, ${ }^{18}$ highlighted that the states parties express their determination "to put an end to impunity for the perpetrators of crimes and thus to contribute to the 'prevention' of such crimes." 19 The "prevention" role given to the ICC stems from the view that courts can prevent crimes through punishments that have a deterrent effect, though, to date, arguably no such punishments have been severe enough to achieve that.

My own experience leads me to believe that you do not have to choose between peace and justice; you can phase them in according to the circumstances-i.e., what the demands of peace suggest. The removal of Charles Taylor from Liberia in 2003 is a case in point. If he had not been taken out of Liberia by prior arrangement involving the African Union, the Economic Community for West African States (ECOWAS) and Nigeria, it is hard to imagine what fate may have befallen the country he led for 6 years. The peace process would probably never have gotten off the ground. And although justice may have been delayed in Taylor's case because of the imperative of peace, eventually it too would be achieved.

\section{Factoring Implementation Agreements into Mediation Efforts}

A second challenge is the need to factor implementation arrangements into the mediation process. The UN is often asked to help the parties implement agreements that were reached without its involvement, that sometimes go against fundamental UN principles, and, moreover, that offer no practical possibilities for implementation. For example, an agreement may hold unrealistic expectations of international support, or a 
timetable which neither party can manage. As a general rule, those institutions which are expected to support implementation should also be present, at least as an observer, during the negotiations.

\section{Ensuring Strong Women's Participation in Conflict Resolution}

A third challenge is women's inclusion in the negotiation and mediation process, rather than just "civil society participation." The UN, like other governmental and inter-governmental bodies, has too few women engaged in these tasks. Although the AU and all the regional economic communities (RECs) in Africa have made laudable strides, boasting gender units and improved means of gender mainstreaming, ${ }^{20}$ to the extent that the AU declared the 2010s to be the African Women's Decade (AWD), ${ }^{21}$ the vision is yet to be realized. Studies have shown that women tend to be better at conflict management, have better listening skills, more tolerance, and empathy. ${ }^{22}$ Africa is losing out for not doing more to rectify gender imbalances in conflict resolution and mediation.

\section{Managing Spoilers Through Innovative Approaches: Inducements, Socializations, Coercion, and Leverage}

The UN does not have the luxury of not engaging spoilers-the fourth challenge-in peace processes in which the organization is involved. (How can one change their behavior without engagement?) The issue for the UN is what kind of engagement is most appropriate or capable of providing deliverables. In this regard, and with the caveat below, I endorse Stephen Steadman's broad categories of engaging spoilers. ${ }^{23}$

\section{The Inducement or Carrots Strategy}

This strategy consists of accepting all the demands of a spoiler in exchange for concessions in the peace process. These demands can include recognition or legitimacy, physical protection by UN troops, economic or political benefits. The inducement approach is the easiest strategy to implement. Unfortunately, when used improperly it can exacerbate the situation, as occured in Angola in 1992 when custodians permitted the National Union for the Total Independence of Angola (UNITA) to play a continued role in the negotiations despite resuming war. On the other hand, in Cyprus, the UN Peace Plan 2004 and the 8th of July Agreement 
were designed to keep the two opposing communities strictly engaged in the peace process.

\section{The Socialization Strategy}

This strategy demands that spoilers conform to a set of norms and standards to be allowed into the peace process. For socialization to be effective, norms must be fair and realistic, they must be clearly established, communicated to all stakeholders and remain consistent over time.

\section{Coercion or Stick Strategy}

This strategy relies on the threat or reality of punishment. This approach includes coercive diplomacy, the use of force, the muted withdrawal of peacekeepers or other international forces, the imposition of "no-fly" zones, and the "departing train" strategy, which is meant to convey to spoilers that the peace process will proceed with or without them. The coercion strategy requires active measures to protect the parties engaged in the peace process and to deter spoilers. The "withdrawal" strategy is not to be considered lightly, given the disastrous experience of Rwanda, where the UN mission was hastily scaled back at the outbreak of the genocide, leading to even greater loss of life. ${ }^{24}$ Needless to say, there should be no exit of UN peacekeeping operations without a clear strategy.

\section{Exercising Leverage}

A fifth challenge is the appropriate exercise of leverage in support of peacebuilding and conflict prevention. A lot has been written about sticks and carrots. I would draw attention to three types of leverage that are sometimes undervalued and therefore underutilized:

i. Leverage which accrues when a mediator builds a relationship of trust with the parties, so that they will have sufficient confidence to ask for advice and be amenable to accept the mediator's suggestions. Mediators need to be prepared to invest personally in building such relationships.

ii. Leverage that results from being able to mobilize impartial technical expertise. While peace processes are fundamentally political in nature, technical advice can sometimes help to find a way out of an impasse, not least by giving the parties a common professional language or set of concepts to work with. 
iii. Leverage in the form of "enabling resources," which can help a party to carry out its side of the bargain, e.g., assistance given to a guerrilla army to transform itself into an effective political party.

\section{Promoting Cohesion among Mediators and Good Offices through Support for a Unified Mediator}

A sixth challenge is the proliferation of actors involved in mediation. Overall this is a positive development. While the UN is the best placed to succeed in some cases, in other situations one of its partners, such as the AU, European Union, or ASEAN may have a comparative advantage. Under Chapter VIII of its Charter, the UN encourages regional organizations to assist in areas of peace and security. This can be seen in the support the UN gives to the AU and their ongoing cooperation in peace operations, which has so far proved more effective than unilateral undertakings. Ultimately, success often rests on the ability of all actors involved to unify behind a chief mediator. The proclivity of actors to "shop around" for the forum that best suits their interests is an ever-present danger in any peacebuilding environment.

Besides stature and expertise, the qualities that make up an effective chief mediator include but are not limited to: impartiality, patience, humility, and respectfulness. The chief mediator must know when to walk away if a peace process comes to a dead-end, the trust and confidence of the parties involved have dissolved, or the mediator has become the "issue" rather than the substance of the conflict.

\section{Relations with NGOs and Civil Society Groups}

At the height of the conflict in Darfur, over 300,000 people were dead and 2 million were internally displaced and living in camps, out of a total population of 7 million. Peacekeepers were tasked with facilitating the delivery of humanitarian assistance to those in need, but it was the NGOs and the wider humanitarian community who were responsible for providing for the basic needs of Darfurians in the camps. Their essential role in delivering food, clothing, education, and health assistance cannot be understated.

Insofar as the peace process, however, the place of NGOs - the seventh and last challenge-became much more complicated and contested. By design or default, they became advocates for one or other armed movements. In effect, they took sides in Darfur, as they have done elsewhere. 
Whenever this occurs, the UN or chief mediator is placed in an invidious position, as their role is to reconcile not take sides. Consequently, it is not uncommon for relationships with NGOs to sour or even break down. This must be avoided at all costs, however. Regular engagement with NGOs is essential; it is not optional. Without NGOs, victims of war would have no one to turn to, and their voices would go largely unheard.

\section{CONClusion}

The Preamble of the Charter of the United Nations starts with the words: "We the People." It is a recognition that the raison d'etre of the world body, i.e., the prevention and resolution of wars and conflict, is far too important to be left to countries and their governments alone.

The UN Charter is clear that the Security Council, and by implication its five permanent members, have primary responsibility for the maintenance of international peace and security. In addition, Chapter VIII of the Charter provides for regional arrangements to complement the efforts of the United Nations. My long experience of peacebuilding in Africa-as mediator, envoy, practitioner, and thinker-leaves me in no doubt that regional organizations must, and are best suited to, initiate conflict resolution efforts and do the heavy-lifting, before the UN enters the arena as a partner and takes over peacekeeping duties. Yet, to paraphrase the late Lord Caradon, former Ambassador/Permanent Representative of the United Kingdom: the United Nations is only as strong as member states allow it to be in terms of preventing, managing, and resolving wars and violent conflict. This is also applicable to regional organizations such as the African Union.

Effective action for peace by the United Nations and regional organizations increasingly depends on the pressure NGOs, scholars, activists, and ordinary citizens bring to bear on their governments and political leaders. Much more needs to be done to safeguard human rights everywhere and to peacefully resolve violent conflicts. This was the inspiration behind the establishment of the Savannah Centre for Diplomacy, Democracy and Development (SCDDD) ${ }^{25}$ and other like-minded institutes and organizations the world over. To paraphrase the motto of the United Nations Educational, Scientific and Cultural Organization (UNESCO): 
since wars begin in people's minds, it is in these same minds that the defense of peace must be constructed.

\section{Key Recommendations}

1. Pay more attention to sequencing of peace and justice-it is not an either/or trade-off. Mindful that the deterrent effect of International Criminal Court indictments on preventing crimes is, at best, unproven, peacebuilding requires flexibility on the timing of peace and justice processes. The context should determine what is appropriate, not arbitrary deadlines set by outsiders.

2. Women must be central to peacebuilding processes, not included as part of a civil society component. Africa is losing out by not doing more to rectify gender imbalances in conflict resolution and mediation.

3. Build support and create new mechanisms for developing a Unified Mediator. Today's peacebuilding environments are replete with multiple actors leveraging different platforms off against one another to advance their own interests. Yet success in peacebuilding often rests on actors rallying behind a single chief mediator who commands support across the political landscape.

Acknowledgement The author thanks Moses Ohaegbuchi, for research assistance in preparing this chapter.

\section{Notes}

1. Forcibly Displaced: Toward a Development Approach Supporting Refugees, the Internationally Displaced, and Their Hosts (Washington, DC: World Bank, 2017), https://openknowledge.worldbank.org/handle/10986/ 25016.

2. Human Security Report 2005: War and Peace in the 21st Century (Vancouver: Human Security Center, 2005).

3. Ben Shepherd, "The 'Spoiler' Concept, Conflict and Politics: Who 'Spoils' What, from Whom?," 2010, http://www.lse.ac.uk/internationa lRelations/dinamfellow/docs/dinamshepherdspoilers.doc.

4. Brugno Stagno Ugarte, "The UN Security Council and Africa: Playing New Games and Applying New Rules and Moves," in The Palgrave Handbook of Peacebuilding in Africa, Tony Karbo and Kudrat Virk (eds.) (Cham: Palgrave Macmillan, 2018), 177-194. 
5. Ugarte, "The UN Security Council and Africa," 177-194.

6. Ibrahim A. Gambari, The Palgrave Handbook of Peacebuilding in Africa, Tony Karbo and Kudrat Virk (eds.) (Cham: Palgrave Macmillan, 2018), 195-208.

7. Ugarte, "The UN Security Council and Africa," 177-194.

8. Ghali B. Boutros, "An Agenda for Peace: Preventive Diplomacy, Peacemaking and Peacekeeping. Report of the Secretary-General," United Nations, June 17, 1992, 5.

9. Koffi Annan, "In Larger Freedom: Towards Development, Security and Human Rights for All. Report of the Secretary-General," United Nations, 2005.

10. The UN plan of 2004 known as the "Annan Plan" and the July 8, 2006 Agreement called the "Gambari Plan."

11. Alvaro de Soto, "Another False Dawn," New York Times, March 28, 2008, https://www.nytimes.com/2008/03/28/opinion/28iht-edd esoto.6.11494850.html.

12. African Union Peace and Security Council, "Report of the African Union High-Level Panel on Darfur (Darfur: The Quest for Peace, Justice and Reconciliation)" (Addis Ababa: African Union, October 2009).

13. Francis M. Deng, "Preventing Mass Atrocities in Africa: The Case of the Two Sudans," in The Palgrave Handbook of Peacebuilding in Africa, Tony Karbo and Kudrat Virk (eds.) (Cham: Palgrave Macmillan, 2018), 103118.

14. Abel Alier, Southern Sudan: Too Many Agreements Dishonoured, 2nd ed. (Ithaca: Exeter, 1999).

15. Gambari, "The Politics of Peacekeeping."

16. Ibid.

17. Secretary-General's remarks to the Ministerial Meeting of the Security Council on Justice and the Rule of Law: The United Nations Role, 2003.

18. Rome Statute of the International Criminal Court, 2187 UNTS 90, July 17, 1998, entry into force January 1, 2002.

19. Rome Statue, fifth preambular paragraph.

20. Zanele Khumalo and Antonia Porter, "Promoting Gender Equality and Empowering Women (MDG Three)," in Africa and the Millenium Development Goals: Progress, Problems, and Prospects, Charles Mutasa and Mark Paterson (eds.) (Lanham: Rowman \& Littlefield, 2015).

21. Antonia Porter, "Women, Gender and Peacebuilding," in The Palgrave Handbook of Peacebuilding in Africa, Tony Karbo and Kudrat Virk (eds.) (Cham: Palgrave Macmillan, 2018), 317-337.

22. Barbara Tedrow and Robert A. Rhoads, "A Qualitative Study of Women's Experiences in Community College Leadership Positions," Community College Review 27, no. 3 (December 1999): 1-18. 
23. Stephen Stedman, "Spoiler Problems in Peace Processes" in International Security 22, no. 2 (1997): 5-53. Stedman defines "spoilers" as "leaders and parties who... use violence to undermine attempts to achieve (peace)."

24. Ibrahim A. Gambari, "Rwanda: An African Perspective," in The UN Security Council: From the Cold War to The 21st Century, David M. Malone (ed.) (Boulder, CO: Lynne Rienner, 2004), 512-520.

25. The Savannah Centre for Diplomacy, Democracy and Development (SCDDD) is an Abuja, Nigeria based non-governmental think-tank on research and policy studies on conflict prevention and resolution as well as democratization and development in Africa. SCDDD seeks to promote the evolution of Africa into a prosperous, politically stable and globally respected continent which is motivated by the culture of good governance.

Open Access This chapter is licensed under the terms of the Creative Commons Attribution 4.0 International License (http://creativecommons.org/licenses/ by $/ 4.0 /$ ), which permits use, sharing, adaptation, distribution and reproduction in any medium or format, as long as you give appropriate credit to the original author(s) and the source, provide a link to the Creative Commons license and indicate if changes were made.

The images or other third party material in this chapter are included in the chapter's Creative Commons license, unless indicated otherwise in a credit line to the material. If material is not included in the chapter's Creative Commons license and your intended use is not permitted by statutory regulation or exceeds the permitted use, you will need to obtain permission directly from the copyright holder.

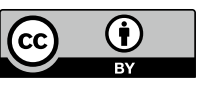

